\title{
INVESTIGATION OF KONYA CITY CULTURAL HERITAGE MANAGEMENT AND SUSTAINABLE URBAN DEVELOPMENT RELATIONSHIP
}

\author{
Çiğdem Çiftçi ${ }^{1 *}$, Fatma Kunt ${ }^{2}$ \\ ${ }^{1 *}$ Department of City and Regional Planning, Faculty of Engineering and Architecture, Necmettin Erbakan \\ University, Konya, Turkey; \\ ${ }^{2}$ Department of Environmental Engineering, Faculty of Engineering and Architecture, Necmettin Erbakan \\ University, Konya, Turkey;
}

*Corresponding author: Çiğdem Çiftçi, email: cigdemciftci@konya.edu.tr; drfatmakunt@ gmail.com;

Received May, 2018; Accepted June, 2018; Published July, 2018;

DOI: https://doi.org/10.31407/ijees8402

UOI license: http://u-o-i.org/1.01/ijees/01891778

\begin{abstract}
Cultural heritage protection is one of the most essential components in the transfer of the identity of cities and communities to future generations. The concrete cultural heritage items representing traditional building technologies and social order are being used with the old or new various functions of conservation principles according to the needs of today's modern cities. Literature studies have shown that systematic assessment methods for assessing the relationship between conservation of cultural heritage and sustainable urban development are lacking (Guzman et all.2017). Cultural assets also provide sustainable ecological urban habitats to cities or urban communities to which cultural heritage must be used in the direction of balanced conservation principles. In this study, cultural heritage preservation policies, implementation tools and evaluation will be evaluated with reference to sustainable ecological planning principles at the historical city center where the Konya cultural heritage is predominantly located. At the and of the study the parameters that can be used to measure the relationship between cultural heritage management and sustainable urban development will be discussed in the case of the Konya city historical center
\end{abstract}

Key words: Cultural Heritage Management, Sustainable Urban Development, Urban Development Sustainability Indicators. 